\title{
TEISĖJO ELGESIO, PRIIMTO SPRENDIMO TEISINGUMO VERTINIMŲ IR ASMENYBĖS BRUOŽŲ SĄSAJOS
}

\author{
Ksenija Čunichina, Gintautas Valickas \\ Vilniaus universiteto Filosofijos fakulteto \\ Bendrosios psichologijos katedra \\ Universiteto g. 9/1, LT-01513 Vilnius, Lietuva \\ Telefonas (+370 5) 2667605
}

Elektroninis paštas ksenija.voropaj@gmail.com; gintautas.valickas@fsf.vu.lt

\author{
Viktoras Justickis \\ Mykolo Romerio universiteto Socialinès politikos fakulteto \\ Psichologijos katedra \\ Ateities g. 20, LT-08303 Vilnius, Lietuva \\ Telefonas (+370 5) 2714620 \\ Elektroninis paštas justickv@takas.lt
}

Pateikta 2014 m. vasario 25 d., parengta spausdinti 2014 m. balandžio 18 d.

doi:10.13165/SMS-14-6-1-10

Anotacija. Straipsnyje analizuojamos teisejjo elgesio atitikties procedūrinio teisingumo reikalavimams, jo elgesio ir priimto sprendimo suvokto teisingumo, taip pat asmenybès bruožu sąajos. Siekiant nustatyti minètas sąajas, taip pat teisejo elgesio atitikimo procedūrinio teisingumo reikalavimams ịtaka jo elgesio ir priimto sprendimo teisingumo vertinimams, buvo atliktas kvazieksperimentas. Tyrime dalyvavo 392 asmenys, kurie buvo suskirstyti į tris grupes. Kiekviena tiriamuju grupe stebejo viena iš triju specialiai parengtu 20 min. trukmès teismo posèdžiu inscenizacijų, kurios skyrèsi tik teisèjo elgesio atitikimu procedürinio teisingumo reikalavimams. Po to buvo vertinamas tiriamuju suvoktas teisejo elgesio ir jo priimto sprendimo teisingumas, taip pat 
jų asmenybės bruožai (taikème Neo Pi-R klausimyną). Gauti rezultatai parodè, kad teisejo elgesio atitikimas procedūrinio teisingumo reikalavimams daro skirtinga įtaka jo elgesio ir priimto sprendimo teisingumo vertinimams, o asmenybés bruožu, suvokto teisejo elgesio bei jo sprendimo teisingumo vertinimų sąsajos pasireiškia tik kai kuriais atvejais.

Reikšminiai žodžiai: teisèjo elgesys, suvoktas teisèjo elgesio ir priimto sprendimo teisingumas, procedūrinio teisingumo reikalavimai, asmenybès bruožai.

\section{Ivadas}

Teisejo elgesio ir priimto sprendimo suvoktas teisingumas turi ypatingą reikšmę asmens pasitenkinimui bylinejjimosi procesu'. Daugelio tyrimų rezultatai rodo, kad subjektyvus ịsitikinimas bylinèjimosi proceso teisingumu priklauso nuo ginčo metu teisèjo taikytų procedūrų teisingumo (procedūrinio teisingumo) vertinimų ${ }^{2}$. Jau daugiau kaip keturis dešimtmečius tyrèjai bando atskleisti suvokto procedūrinio teisingumo veiksnius, darančius įtaką subjektyviems teisingumo vertinimams. Suvokto teisingumo tyrimus atlieka daugelio socialinių mokslų atstovai (pvz., psichologijos, teisès filosofijos, sociologijos, vadybos). Tačiau kartu reikia pasakyti, kad psichologiniai procedūrinio teisingumo aspektai iki šiol nèra pakankamai išnagrinèti. Šie aspektai ịgyja ypatingą reikšmę tada, kai kalbame apie bylinejjimosi proceso teisingumo vertinimus, kadangi justicija siekia užtikrinti ne tik objektyvųji, bet ir subjektyvųji ginčo sprendimą ${ }^{3}$.

Pastaruoju metu tyrejjai vis dažniau siekia atskleisti subjektyvius veiksnius (pvz., įvairius asmenybės kintamuosius), kurie gali turèti ịtakos ịvairių ginčų teisingumo vertinimams ${ }^{4}$. Asmenybès kintamieji lemia ne tik mūsų elgesị țvairiomis situacijomis bet ir šių situacijų supratimą. Paskutinių dviejų dešimtmečių psichologiniai tyrimai parodè, kad žmonès skiriasi ne tik savo jautrumu frustracijai, apdovanojimui, nežinomybei, bet turi skirtingą jautrumą moralinių normų pažeidimams ir suvoktam

1 Lind, E. A.; Tyler, T. R. The social psychology of procedural justice. New York: Plenum Press, 1988.

2 Ibid., Thibaut, J.; Walker, L. Procedural justice. Hillsdale, New Jersey: Lawrence Erlbaum, 1975; Tyler, T. R. Social justice: Outcome and procedure. International Journal of Psychology. 2000, 35(2): 117-125.

3 Justickis, V.; Valickas, G. Procedūrinis teisingumas Lietuvos kriminalinejje justicijoje. Vilnius: Mykolo Romerio universitetas, 2006.

4 Colquitt, J. A., et al. Justice and personality: Using integrative theories to derive moderators of justice effects.Organizational Behavior and Human Decision Processes. 2006, 100(1): 110-127; Huseman, R. C.; Hatfield, J. D.; Miles, E. W. A new perspective on Equity Theory: The Equity Sensitive Construct. Academy Management Review. 1987, 12(2): 222-234; Schmitt, M.; Dörfel, M. Procedural injustice at work, justice sensitivity, job satisfaction and psychosomatic wellbeing. European Journal of Social Psychology. 1999, 29(4): 443-453. 
neteisingumui ${ }^{5}$. Vieni žmonès gali nekreipti dèmesio ị stebimą neteisingumą, tačiau kitiems tokia situacija gali sukelti stiprias emocines ir elgesio reakcijas ${ }^{6}$. Svarbu pažymèti, kad individualūs žmonių skirtumai atlieka ypač svarbų vaidmenį tomis situacijomis, kai pažeidžiamas teisingumas ${ }^{7}$. Pažeisti teisingumo principai sukelia žmonèms daug neapibrèžtumo, kuris, savo ruožtu, skatina juos priimant sprendimus labiau pasikliauti vidiniais, o ne išoriniais veiksniais ${ }^{8}$.

Tyrimais nustatyta, kad subjektyviems teisingumo vertinimams įtakos gali turèti tokie specifiniai asmenybès kintamieji kaip jautrumas teisingumui ${ }^{9}$, polinkis pasitikèti kitais, rizikos vengimas ${ }^{10}$, kontrolès lokusas ${ }^{11}$ ir pan. Pastaruoju metu tyrèjai pradejjo vis labiau domėtis taksonominių asmenybės bruožų ir suvokto teisingumo sąsajomis. Vienas iš vyraujančių taksonominių asmenybės bruožų aiškinimų - penkių faktorių teorija, sujungianti ị bendrą asmenybės struktūrą penkias bruožų grupes (neurotiškumą, ekstraversiškumą, atvirumą, sutarumą ir sąmoningumą) ${ }^{12}$. Penkių faktorių teorija sulauke didelio tyrinètojų susidomejjimo ${ }^{13}$, kadangi išskirtos bruožų grupès leidžia apibūdinti asmenybès emocinius, tarpasmeninius, patirties, požiūrio ir motyvacinius aspektus, o žemesnio lygio bruožų skalès - atlikti detalesnę asmenybès analizę, matuojant specifinius jos bruožus kiekvienoje iš penkių sričių ${ }^{14}$.

Jau yra nustatytos ir kai kurios asmenybės bruožų bei suvokto teisingumo sąsajos (tačiau reikia pažymėti, kad tyrèjai, nagrinėjantys asmenybės bruožų ir suvokto teisingumo ryšius, dažniausiai dirba organizacinès psichologijos srityje).

5 Schmitt, M. Individual differences in sensitivity to befallen injustice (SBI). Personality and individual differences. 1996, 21(1): 3-20.

6 Baumert, A.; Schmitt, M. Justice sensitive interpretations of ambiguous situations. Australian Journal of Psychology. 2009, 61(1): 6-12.

7 Stouten, J.; Ceulemans, E.; Timmerman, M. E.; Van Hiel, A. Tolerance of Justice Violations: The Effects of Need on Emotional Reactions After Violating Equality in Social Dilemmas. Journal of Applied Social Psychology. 2011, 41(2): 357-380.

8 De Kwaadsteniet, E. W.; Van Dijk, E.; Wit, A.; De Cremer, D. Social dilemmas as strong versus weak situations: Social value orientations and tacit coordination under resource uncertainty. Journal of Experimental Social Psychology. 2006, 42(4): 509-516; Snyder, M.; Ickes, W. Personality and social behavior. Handbook of social psychology. $3^{\text {rd }}$ edition. New York: Random House, 1985, p. 883-948.

9 Huseman, R. C.; Hatfield, J. D.; Miles, E. W., supra note 4; Schmitt, M. Individual differences in sensitivity to befallen injustice (SBI). Personality and Individual Differences. 1996, 21(1): 3-20.

10 Colquitt, J. A., et al., supra note 4.

11 Lilly, J. D.; Virick, M. The effect of personality on perceptions of justice. Journal of Managerial Psychology. 2006, 21 (5): 438-458.

12 Costa, P. T.; McCrae, R. R. Revised NEO Personality Inventory (NEO-PI-R) and NEO Five-Factor Inventory (NEO-FFI) professional manual. Odessa: Psychological Assessment Resources, 1992.

13 Wiggins, J. S.; Trapnell, P. D. Personality structure: The return of the Big Five. Handbook of personality psychology.San Diego: Academic Press, 1997, p. 737-765.

14 Costa, P. T.; McCrae, R. R. Taisyto NEO (NEO PI-R) ir NEO penkiu faktoriu (NEO-FFI) klausimynu vadovas. Vilnius: VU specialiosios psichologijos laboratorija, 2012. 
Neurotiškumas (jis apibūdinamas kaip asmens tendencija patirti neigiamus jausmus $)^{15}$. Nustatyta, kad neurotiški asmenys linkę baimintis naujų situacijų ir dažnai patiria bejejgiškumo bei priklausomybès jausmus ${ }^{16}$. Dalyvavimą bylinejjimosi procese jie gali suprasti kaip stresą sukeliančią patirtį, todèl galima manyti, kad aukšti neurotiškumo skalès įverčiai bus susiję su stipresniu suvoktu neteisingumu. Be to, neurotiškumas siejamas su dažnesniu neigiamų gyvenimo įvykių išgyvenimu ${ }^{17}$. Tyrimais nustatyta, kad neurotiškumas neigiamai susijęs su suvoktu procedūriniu ir informaciniu teisingumu. Kitaip tariant, asmenys, kurie surenka aukštus neurotiškumo skalès ịverčius, sprendimo prièmimo situacijas savo darbovietejje linkę vertinti kaip mažiau teisingas. Kartu jie yra mažiau patenkinti valdžios atstovų elgesiu su jais (palyginti su žemo neurotiškumo asmenimis) ${ }^{18}$.

Ekstraversiškumas (ekstravertai apibūdinami kaip draugiški, linksmi, visuomeniški, atkaklūs ir kalbūs, jiems patinka susijaudinimas bei stimuliacija). Atlikti tyrimai byloja, kad darbuotojų atrankos situacijose ekstraversija yra teigiamai susijusi su suvoktu procedūriniu teisingumu ${ }^{19}$ : ekstravertai yra linkę vertinti darbuotojų atranką kaip palankesnę ir teisingesnę (palyginti su intravertais).

Atvirumas naujai patirčiai (asmenys, surinkę aukštus atvirumo patirčiai skalès ịverčius, apibūdinami kaip lakios vaizduotès, dèmesingi savo vidiniams išgyvenimams, estetiškai jautrūs, besidomintys ne tik vidiniu, bet ir išoriniu pasauliu, taip pat nepriklausomi) ${ }^{20}$. Atvirumas naujai patirčiai neigiamai koreliuoja su tikejjimu pasaulio teisingumu - kuo labiau išreikštas šis bruožas, tuo silpnesnis žmonių įsitikinimas, kad pasaulis yra teisingas ${ }^{21}$.

Sutarumas (sutarūs žmonės yra altruistai, vengiantys ginčų, linkę užjausti kitus ir siekiantys padèti kitiems, be to, jie įsitikinę, kad kiti jiems taip pat bus paslaugūs) ${ }^{22}$. Galima manyti, kad neịprastų, stresą sukeliančių situacijų metu (pvz., dalyvavimas teisme kaip nukentejjusiajam) žemo sutarumo asmenys išgyvens stipresnị emocini sužadinimą, kuris gali paveikti jų suvoktą teisingumą. Remiantis P. T. Costa ir R. R. McCrae (1992), aukšto sutarumo asmenys siekia vengti konfliktų ir konfrontacijos, jiems svarbi parama ir bendradarbiavimas, todèl galima manyti, kad jie lengviau priims nepalankų sau sprendimą.

15

17 Magnus, K.; Diener, E.; Fujita, F.; Pavot,W. Extraversion and neuroticism as predictors of objective life events; a longitudinal study. Journal of Personality and Social Psychology. 1993, 65(5): $1046-1053$.

Costa, P. T.; McCrae, R., supra note 14.

Wiggins, J. S.; Trapnell, P. D., op. cit.

Shi, J.; Lin, H.; Wang, L.; Wang, M. Linking the Big Five Personality Constructs to Organizational Justice. Social Behavior and Personality. 2009, 37(2): 209-222.

9 Wrenn, K. A. The Big Five as Predictors of Procedural Justice Perceptions. Georgia: Georgia Institute of Technology, 2005.

Costa, P. T.; McCrae, R., op. cit.

Wolfradt, U.; Dalbert, C. Personality, Values and Belief in a Just World. Personality and Individual Differences. 2002, 35(8): 1911-1918.

Costa, P. T.; McCrae, R., op. cit. 
Organizacijose atlikti tyrimai byloja, kad aukštus sutarumo ịverčius turintiems žmonèms suvoktas teisingumas turi ypatingą reikšmę. Pavyzdžiui, D. P. Skarlicki kartu su kolegomis (1999) nustatè, kad sutarumas teigiamai koreliuoja su suvoktu procedūriniu teisingumu ir yra neigiamai susijęs su kerštavimu organizacijose. Šiuos duomenis patvirtino ir kiti tyrejai ${ }^{23}$, kurie nustate teigiamą sutarumo ir visų organizacinio teisingumo komponentų (procedūrinio, informacinio, skirstymo ir interakcinio) ryši.

Sąmoningumas (sąmoningi asmenys apibūdinami kaip atsakingi, orientuoti ì pasiekimus, kompetentingi, ryžtingi ir atkaklūs) ${ }^{24}$. Nustatyta, kad asmenys, kuriems būdingi aukšti sąmoningumo skalès ịverčiai, supranta pasauli kaip labiau teisingą (palyginti su tais, kurių sąmoningumo bruožas nera toks išreikštas) ${ }^{25}$. Galima manyti, kad asmenys, kurie turi stipriai išreikštą sąmoningumą, bus atidesni įvairiems ginčo sprendimo aspektams ir smulkmenoms.

Kartu reikia pripažinti, kad dauguma empirinių tyrimų, nagrinėjančių suvokto teisingumo ir asmenybės bruožų ryšius, yra atlikti organizacineje psichologijoje, todèl jų rezultatus ne visada galima pritaikyti analizuojant justicijos problemas (pvz., bylinejjimąsi teisme). Teismo procesas - tai specifinè ir neretai stiprų stresą sukelianti situacija, kurią sunku palyginti su kasdienemis situacijomis, kylančiomis organizacijų veikloje. Reikia pridurti, kad mums nepavyko rasti tyrimų, kurie nagrinètų asmenybės bruožų ir suvokto teisingumo vertinimų sąsajas teisès psichologijos srityje. Kita vertus, nors justicija remiasi daugeliu objektyvių veiksnių (pvz., procesiniuose dokumentuose reglamentuotomis taisyklemis), jų teisingumo vertinimas visada yra subjektyvus. Todell labai svarbu suprasti, su kuo yra labiau susiję suvokto teisingumo vertinimai - su asmens individualiomis charakteristikomis (pvz., asmenybės bruožais), ar su situaciniais veiksniais (pvz., teisejo elgesio atitikimu procedūrinio teisingumo reikalavimams ir priimto sprendimo pobūdžiu). Atsižvelgiant ị tai buvo iškelti tokie tyrimo tikslai: a) nustatyti teisejjo elgesio atitikimo procedūrinio teisingumo reikalavimams ittaką jo elgesio ir priimto sprendimo teisingumo vertinimams; b) nustatyti teisejjo elgesio ir priimto sprendimo suvokto teisingumo, taip pat asmenybès bruožų sąsajas.

\section{Tyrimo metodologija}

Siekiant nustatyti teisejjo elgesio atitikimo procedūrinio teisingumo reikalavimams įtaką suvoktam teisingumui, taip pat suvokto teisingumo ir asmenybès bruožų sąsajas, buvo atliktas kvazieksperimentas. Atliekant kvazieksperimentą, buvo taikytas scenarijų metodas, kuris dažnai taikomas procedūrinio teisingumo tyrimuose ${ }^{26}$. Tai-

24 Barrick, M. R.; Mount, M. K. The big five personality dimensions and job performance: a metaanalysis. Personnel psychology. 1991, 44(1): 1-26.

25 Wolfradt, U.; Dalbert, C., supra note 21.

26 Lind, E. A.; Tyler, T. R., supra note 1. 
kant šị metodą, tiriamos dalyvių reakcijos ne ị realiai patirtas, bet ị ịsivaizduojamas, tyrejo pateiktas hipotetines situacijas. Kvazieksperimente buvo naudojami specialiai šiam tyrimui nufilmuoti trys teisminio bylos nagrinèjimo siužetai (kiekvieno trukmé apie $20 \mathrm{~min}$.). Rengiant teisminio ginčo nagrinèjimo scenarijų, buvo remiamasi: a) Lietuvos Respublikos baudžiamojo ir Baudžiamojo proceso kodeksais; b) realių teismo procesų stebejjimu (stebèta 12 bylų); c) konsultacijomis su teisininkais ir teisès psichologijos ekspertais. Šiame etape buvo nuspręsta pasirinkti baudžiamųjų, o ne civilinių bylų nagrinejjimo teisme situaciją. Scenarijaus fabuloje buvo nuspręsta pasirinkti dažniausiai (2012 m. Lietuvos statistikos departamento duomenimis) mūsų šalyje padaromus nusikaltimus - plěšimą ir sunkų sveikatos sutrikdymą.

Lietuvos Respublikos baudžiamojo proceso kodekso V dalies (Bylų procesas pirmosios instancijos teisme) 241-296 straipsnių pagrindu buvo parengti trys tos pačios bylos nagrinejimo scenarijai. Visuose scenarijuose teismo proceso dalyvių (advokato, prokuroro, sekretorès, kaltinamojo ir nukentëjusiojo) elgesys nesiskyré, tačiau teisèjo elgesys kiekviename scenarijuje buvo skirtingas (skyrèsi teisèjo elgesio atitikimas procedūrinio teisingumo reikalavimams). Pirmajame scenarijuje teisèjo elgesys visiškai atitinka procedūrinio teisingumo reikalavimus: jis su visais ginčo dalyviais elgiasi pagarbiai, deda pastangas, siekdamas užtikrinti teisingas ginčo sprendimo procedūras, suteikia kaltinamajam bei nukentejusiajam galimybę išreikšti savo nuomonę ir pan. Antrajame scenarijuje teisèjo elgesys iš dalies atitinka procedūrinio teisingumo reikalavimus: nors jis nepažeidžia Lietuvos Respublikos baudžiamojo proceso kodekse reglamentuotos teismo proceso eigos, tačiau su ginčo šalimis elgiasi formaliai, nededa daug pastangų siekdamas išspręsti ginčą, greitai perskaito proceso dalyvių teises ir nesigilina, ar jie jas supranta ir pan. Trečiajame scenarijuje teisèjo elgesys neatitinka procedūrinio teisingumo reikalavimų - jis nesidomi ir neišklauso ginčo šalių, nepagarbiai komentuoja jų pasisakymus, skubina procesą ir pan. Pagal paruoštus scenarijus buvo nufilmuoti ir sumontuoti trys vaizdo įrašai. Siekiant užtikrinti, kad vaizdo įrašai skirtųsi pagal teisejo elgesio atitikimą procedūrinio teisingumo reikalavimams, jie buvo pateikti 4 vertintojams - klinikiniams psichologams (2 vyrams ir 2 moterims), kurie turejjo ne mažiau kaip 2 metų konsultavimo praktiką. Peržiūrẻję vaizdo medžiagą, vertintojai iš karto vertino teisejo elgesio atitikimą procedūrinio teisingumo reikalavimams, taikydami 10 teiginių skalę (skalès Kronbacho $\alpha=0,87$ ). Buvo vertinami tokie teisèjo elgesio aspektai: a) elgesio nešališkumas; b) mandagumas ir etiškumas; c) geranoriškas bendravimas; d) ịsitraukimas ị bylinèjimosi procesą; e) ginčo šalims suteikiama galimybe pasisakyti; f) pastangos išsamiai paaiškinti bylos nagrinèjimo tvarką; g) teisių ir pareigų išaiškinimo pobūdis; $h$ ) susidomèjimo byla demonstravimas neverbaline kalba; i) ginčo dalyviams suteikta galimybe užduoti klausimus; $h$ ) dėmesingumas klausantis ginčo šalių parodymų. Teisėjo elgesys buvo vertinamas taikant 7-ių balų Likerto skalę (nuo labai silpnai išreikšto iki labai stipriai išreikšto). Blokuotų duomenų dispersinė analizè ir daugkartinio palyginimo (taikytas Bonferonio kriterijus) rezultatai atskleidè, kad teisèjo elgesys trijuose stimulinès medžiagos variantuose yra skirtingas ir atitinka scenarijaus užmanymą $(F=270,514$, 
$\mathrm{p}<0,001, \eta^{2}=0,989$ ). Žemiausi balai buvo priskirti trečiajam (neatitinkančiam procedūrinio teisingumo reikalavimų), aukščiausi - pirmajam (visiškai atitinkančiam procedūrinio teisingumo reikalavimus) ir vidutiniai - antrajam (dalinai atitinkančiam procedūrinio teisingumo reikalavimus) scenarijaus variantui (žr. 1 lentelę).

1 lentelè. Stimulinès medžiagos vertinimų skirtumų rodikliai

\begin{tabular}{|c|l|c|c|}
\hline $\begin{array}{c}\text { (I) Teisèjo elgesio } \\
\text { atitikimas } P T^{*} \\
\text { reikalavimams }\end{array}$ & $\begin{array}{c}\text { (J) Teiséjo elgesio } \\
\text { atitikimas } P T \\
\text { eikalavimams }\end{array}$ & $\begin{array}{c}\text { Skirtumo vidurkis } \\
(I-J)\end{array}$ & $\begin{array}{c}\text { Reikšmingumo } \\
\text { lygmuo } \\
(\text { p reikšmé) }\end{array}$ \\
\hline \multirow{2}{*}{ Visiškai atitinka } & Iš dalies atitinka & 1,675 & 0,002 \\
\cline { 2 - 4 } & Neatitinka & 2,875 & 0,001 \\
\hline Iš dalies atitinka & Neatitinka & 1,200 & 0,009 \\
\hline
\end{tabular}

${ }^{*} P T$ - procedūrinis teisingumas

\subsection{Ivvertinimo būdai}

Suvokto teisingumo vertinimams atlikti buvo parengta speciali metodika. Ją kurdami rèmėmès lietuvių ir užsienio autorių darbais, nagrinèjančiais suvoktą teisèsaugos pareigūnų elgesio teisingumą $a^{27}$. Buvo vertinami du svarbiausi suvokto teisingumo aspektai: a) teisèjo elgesio teisingumas; b) teisejo priimto sprendimo teisingumas.

Teiséjo elgesio teisingumo vertinimas. Teisejo elgesio teisingumo skalę sudarè 5 subskalès, kiekviena po 3 teiginius: a) procedūrinio teisingumo; b) galimybès išreikšti savo nuomonę; c) etiškumo; d) nešališkumo; e) teisèjo pastangų. Teiginiai buvo vertinami taikant Likerto skalę nuo 1 (visiškai nesutinku) iki 7 (visiškai sutin$\mathrm{ku}$ ). Teisèjo elgesio teisingumo skalès vidinis suderinamumas yra aukštas (Kronbacho $\alpha=0,906)$. Siekdami patikrinti, kiek konstruktų sudaro teisèjo elgesio teisingumo skalès teiginiai, atlikome principinių komponenčių faktorių analizę su Varimax sukiniu. Gauti rezultatai parodé, kad duomenys tinka faktorių analizei: $\mathrm{KMO}=0,923$, Bartleto sferiškumo testo kriterijus $\chi^{2}=5144,27, \mathrm{p}<0,001$. Faktorinès analizės rezultatai rodo, kad 5 faktoriai paaiškina 78 proc. duomenų išsibarstymo ir logiškai atitinka skalès užmanymą. Skalès teiginių faktoriniai svoriai kiekviename iš penkių faktorių svyruoja nuo 0,67 iki 0,84 .

27 Laurinavičius, A. Procedūrinio teisingumo psichologiniai veiksniai: Teisëjo sprendimo prognozés itaka teisingumo vertinimams.Daktaro disertacija. Socialiniai mokslai, psichologija. Vilnius: Vilniaus universitetas, 2006; Orth, U. Secondary victimization of crime victims by criminal proceedings. Social Justice Research. 2002, 15(4): 313-325; Elliott, I.; Thomas, S. D. M.; Ogloff, J. R. P. Procedural justice in contacts with the police: Testing a relational model of authority in a mixed methods study. Psychology, Public Policy, and Law. 2011, 17(4): 592-610. 
Teisejjo priimto sprendimo teisingumo vertinimas. Teisèjo priimto sprendimo teisingumo skalę sudare 3 teiginiai (pvz., „Teisėjo priimtas sprendimas yra teisingas"), kurie buvo vertinami taikant Likerto skalę nuo 1 (visiškai nesutinku) iki 7 (visiškai sutinku). Vidinis skalès suderinamumas yra aukštas (Kronbacho $\alpha=0,926)$. Siekdami patikrinti sprendimo teisingumo skalès konstrukto validumą, atlikome principinių komponenčių faktorių analizę. Gauti rezultatai parodè, kad duomenys tinka faktorių analizei: $\mathrm{KMO}=0,76$, o Bartleto sferiškumo testo kriterijus $\chi^{2}=1161,48$, $\mathrm{p}<0,001^{28}$. Faktorių analizès rezultatai leidžia teigti, kad sprendimo teisingumo skalę sudaro vienas faktorius, kuris paaiškina 88 proc. duomenų išsibarstymo.

Asmenybès bruožų vertinimas. Tiriamųjų asmenybės bruožai buvo matuojami taisyto NEO asmenybės klausimyno (NEO-PI-R) (autoriai P. T. Costa ir R. R. McCrae, 1992) lietuviškosios versijos $S$ forma. Ši klausimyno forma skirta paties tiriamojo savęs ịvertinimui, ją sudaro 240 teiginių, kurie vertinami taikant 5 balų skalę. NEOPI-R - tai Lietuvoje adaptuotas normalių asmenybès bruožų matavimo instrumentas, naudojamas ne tik klinikiniuose, bet ir moksliniuose tyrimuose. Klausimyno teiginiais yra ịvertinami asmenybės bruožai pagal 5 didžiuosius asmenybės faktorius (dimensijas): neurotiškumo $(\mathrm{N})$, ekstravertiškumo $(\mathrm{E})$, atvirumo $(\mathrm{O})$, sutarumo $(\mathrm{A})$, sąmoningumo (C). Atskirų faktorių skalių Kronbacho a koeficientai svyravo nuo 0,847 iki 0,907, o tai leidžia teigti, kad vidinis skalių suderintumas yra aukštas ${ }^{29}$.

\subsection{Tiriamieji}

Tyrime dalyvavo 415 Vilniaus universiteto ir Lietuvos edukologijos universiteto studentų. Galutiniame tyrimo etape buvo analizuojami 392 tiriamųjų atsakymai. Kai kurių tiriamųjų atsakymai buvo pašalinti dèl netinkamo skalių ar klausimyno užpildymo arba dèl neteisingo kvazieksperimento sąlygų supratimo. Galutinę 392 tiriamųjų imtį sudarè: 47,7 proc. vyrų $(n=187)$ ir 52,3 proc. moterų $(n=205)$. Tiriamųjų amžius svyravo nuo 18 iki 34 metų (vidurkis - 20,28; standartinis nuokrypis - 1,7). Didžiąją tiriamųjų dalị sudare 18-20 metų (280 dalyvių, 71,4 proc.) ir 21-23 metų (96 dalyviai, 24,5 proc.) asmenys.

Tiriamieji buvo suskirstyti $\mathfrak{i}$ tris grupes; kiekvienos grupès dalyviams buvo pateiktas vienas iš trijų stimulinės medžiagos variantų. Pirmąji siužetą (visiškas teisèjo elgesio atitikimas procedūrinio teisingumo reikalavimams) žiūrèjo 132 tiriamieji, antrąji (dalinis teisèjo elgesio atitikimas procedūrinio teisingumo reikalavimams) siužetą žiūrèjo 144, o trečiąji (neatitinkantis procedūrinio teisingumo reikalavimų) - 116 asmenų. Pagal tiriamųjų skaičių šios grupess statistiškai reikšmingai nesiskyrè $\left(\chi^{2}=3,02, p=0,22\right)$. Taip pat buvo patikrintas eksperimentinių grupių homogeniškumas pagal socialines-demografines charakteristikas. Statistinè analizè atskleidè, kad dinè priemonè. Vilnius: VU leidykla, 2012, p. 46. 
grupès statistiškai reikšmingai nesiskiria pagal amžių $\left(\chi^{2}=7,33, p=0,5\right)$, viktimizacinę patirtị $\left(\chi^{2}=4,89, \mathrm{p}=0,09\right)$, patirtos nusikalstamos veikos pobūdị $\left(\chi^{2}=3,03\right.$, $\mathrm{p}=0,55)$, kreipimąsi į teisèsaugą patyrus nusikaltimą $\left(\chi^{2}=1,36, \mathrm{p}=0,51\right)$, pažįstamų dalyvavimo teisme patirtị $\left(\chi^{2}=0,823, p=0,66\right)$, pažistamųjų atsiliepimus apie teismus $\left(\chi^{2}=8,18, p=0,09\right)$, nuomonę apie Lietuvos teismus $\left(\chi^{2}=8,22, p=0,08\right)$, doméjimąsi teisinès tematikos spauda $\left(\chi^{2}=4,65, p=0,09\right)$, lyti $\left(\chi^{2}=2,38, p=0,3\right)$, dalyvavimo teisme patirti $\left(\chi^{2}=0,103, p=0,94\right)$. Taigi apibendrinant galima teigti, $\mathrm{kad}$ kvazieksperimento tiriamųjų grupès pagal socialines-demografines charakteristikas buvo homogeniškos.

\subsection{Tyrimo eiga}

Tyrimą sudarė 4 etapai. Pirma, tiriamiesiems buvo trumpai pristatomas tyrimo tikslas, prašoma atsakyti i sociodemografinius klausimus bei leidžiama susipažinti su bylos fabula. Pateikiant bylos aprašymą buvo sąmoningai pabréžiama, kad nors kaltinamasis nepripažįsta savo kaltès, visi ịrodymai apie ją byloja. Tokiu būdu buvo siekiama, kad tiriamieji tikètųsi, jog teisèjas priims nukentejusiajam palankų sprendimą. Antra, tiriamųjų buvo prašoma įsivaizduoti save nusikaltimo aukos vietoje ir stebèti teismo proceso inscenizaciją iš nukentejusiojo pozicijos. Tiriamiesiems buvo rodomas vienas iš trijų filmuotos medžiagos variantų. Po vaizdo medžiagos peržiūros tiriamųjų buvo prašoma susipažinti su teisejjo priimtu sprendimu. Teisèjo priimtas sprendimas buvo toks: „Išnagrinėjęs posėdžio metu pateiktus įrodymus ir argumentus, teismas nusprendè nuteisti kaltinamąji 2 metais laisvès atemimo ir tik iš dalies patenkinti nukentėjusiosios reikalavimus atlyginti žalą: turtinẻ žala buvo atlyginta visiškai, neturtinè žala buvo atlyginta tik iš dalies“. Po to tiriamųjų buvo prašoma atsakyti ị klausimus, susitapatinus su nusikaltimo auka. Pirma, tiriamieji turèjo ịvertinti, kiek teisèjo priimtas sprendimas ir kaltinamajam skirta bausmė atitiko jų lūkesčius (vertinant iš nukentejjusiojo pozicijos). Pagal tyrimo užmanymą buvo svarbu, kad tiriamųjų lūkesčiai teisèjo sprendimo ir paskirtos bausmès atžvilgiu būtų nepateisinti teisèjo priimtas sprendimas turèjo būti ịvertintas kaip nepakankamai griežtas. Mes neanalizavome tų tiriamųjų atsakymų, kurie tikèjosi švelnesnès bausmès kaltinamajam arba panašios ị tą, kurią paskyrè teisèjas, taip pat kurie teisėjo priimtą sprendimą vertino kaip palankų arba kaip nei palankų, nei nepalankų (iš viso dèl neatitikimo šių sąlygų buvo atmesta 15 tiriamųų atsakymų). Užpildyti klausimynai buvo surenkami, o tiriamiesiems po to buvo išdalinamas asmenybės bruožų ịvertinimo klausimynas. Vidutiné viso tyrimo trukmè - nuo 60 iki 90 minučių.

\section{Tyrimo rezultatai}

Atlikdami statistinę analizę, taikème vienfaktorinès dispersinès (ANOVA) ir kovariacinès analizès (ANCOVA) statistinius metodus. Gauti rezultatai, pateikti 2 lentelèje, rodo, kad teisejjo elgesio pobūdis daro įtaką jo elgesio ir priimto sprendimo teisingumo vertinimams. 
2 lentele. Teisèjo elgesio pobūdžio įtaka suvokto teisingumo vertinimams (dispersinès analizès rezultatai)

\begin{tabular}{|c|c|c|c|c|c|c|}
\hline \multirow[t]{3}{*}{ Suvokto teisingumo skales } & \multirow{2}{*}{\multicolumn{3}{|c|}{$\begin{array}{c}\text { Vidurkiai } \\
\text { Teisèjo elgesio pobūdis }\end{array}$}} & \multirow{3}{*}{$\begin{array}{c}F \\
\text { reikšme }\end{array}$} & \multirow[t]{3}{*}{ p reikšmé } & \multirow[t]{3}{*}{$\eta^{2}$} \\
\hline & & & & & & \\
\hline & \begin{tabular}{|c|} 
Neatitinka \\
$P T^{\star}$ reika- \\
lavimu
\end{tabular} & $\begin{array}{c}\text { Iš dalies } \\
\text { atitinka PT } \\
\text { reikalavi- } \\
\text { mus }\end{array}$ & \begin{tabular}{|c|} 
Visiškai \\
atitinka PT \\
reikalavi- \\
mus
\end{tabular} & & & \\
\hline $\begin{array}{l}\text { Priimto sprendimo } \\
\text { teisingumas }\end{array}$ & 2,68 & 3,73 & 3,32 & 16,42 & $\mathrm{p}<0,001$ & 0,078 \\
\hline $\begin{array}{l}\text { Bendras teisejjo elgesio } \\
\text { teisingumas ( } 5 \text { skalių } \\
\text { vidurkis) }\end{array}$ & 3,19 & 4,80 & 5,30 & 202,85 & $\mathrm{p}<0,001$ & 0,511 \\
\hline Procedūrų teisingumas & 2,36 & 4,30 & 4,72 & 119,18 & $\mathrm{p}<0,001$ & 0,380 \\
\hline $\begin{array}{l}\text { Galimybė išreikšti savo } \\
\text { nuomonę }\end{array}$ & 4,18 & 5,03 & 5,48 & 42,03 & $\mathrm{p}<0,001$ & 0,178 \\
\hline Etiškumas & 2,32 & 5,09 & 5,87 & 299,89 & $\mathrm{p}<0,001$ & 0,607 \\
\hline Nešališkumas & 3,63 & 4,98 & 5,36 & 84,98 & $\mathrm{p}<0,001$ & 0,304 \\
\hline Teisejjo pastangos & 3,45 & 4,65 & 5,04 & 61,64 & $\mathrm{p}<0,001$ & 0,241 \\
\hline
\end{tabular}

${ }^{*} \mathrm{PT}$ - procedūrinis teisingumas

Siekdami nustatyti, kurių tiriamųjų grupių teisėjo elgesio ir priimto sprendimo teisingumo vertinimai skiriasi, atlikome daugkartinius palyginimus (taikytas Bonferonio kriterijus) (žr. 3 lentelę).

3 lentelè. Teisejo elgesio ir priimto sprendimo teisingumo vertinimų palyginimas skirtingomis teisèjo elgesio situacijomis (daugkartinių lyginimų rezultatai)

\begin{tabular}{|c|c|c|c|c|}
\hline $\begin{array}{l}\text { Suvokto } \\
\text { teisingumo } \\
\text { skales }\end{array}$ & (I) Teisèjo elgesys & (J) Teisèjo elgesys & $\begin{array}{c}\text { Vidurkiu } \\
\text { skirtumas } \\
\quad(I-J)\end{array}$ & $\begin{array}{c}\text { Reikšmin- } \\
\text { gumo } \\
\text { lygmuo }\end{array}$ \\
\hline \multirow[t]{3}{*}{$\begin{array}{l}\text { Sprendimo } \\
\text { teisingumas }\end{array}$} & \multirow{2}{*}{$\begin{array}{l}\text { Neatitinka } \mathrm{PT}^{*} \\
\text { reikalavimų }\end{array}$} & $\begin{array}{l}\text { Iš dalies atitinka PT } \\
\text { reikalavimus }\end{array}$ & $-1,045$ & $\mathrm{p}<0,001$ \\
\hline & & $\begin{array}{l}\text { Visiškai atitinka PT } \\
\text { reikalavimus }\end{array}$ & $-0,639$ & $\mathrm{p}<0,001$ \\
\hline & $\begin{array}{l}\text { Iš dalies atitinka } \mathrm{PT} \\
\text { reikalavimus }\end{array}$ & $\begin{array}{l}\text { Visiškai atitinka PT } \\
\text { reikalavimus }\end{array}$ & 0,405 & 0,066 \\
\hline
\end{tabular}




\begin{tabular}{|c|c|c|c|c|}
\hline \multirow[t]{3}{*}{$\begin{array}{l}\text { Elgesio } \\
\text { teisingumas }\end{array}$} & \multirow{2}{*}{ Neteisingas elgesys } & $\begin{array}{l}\text { Iš dalies atitinka PT } \\
\text { reikalavimus }\end{array}$ & $-1,606$ & $\mathrm{p}<0,001$ \\
\hline & & $\begin{array}{l}\text { Visiškai atitinka PT } \\
\text { reikalavimus }\end{array}$ & $-2,107$ & $\mathrm{p}<0,001$ \\
\hline & $\begin{array}{l}\text { Iš dalies atitinka PT } \\
\text { reikalavimus }\end{array}$ & $\begin{array}{l}\text { Visiškai atitinka PT } \\
\text { reikalavimus }\end{array}$ & $-0,500$ & $\mathrm{p}<0,001$ \\
\hline \multirow[t]{3}{*}{$\begin{array}{l}\text { Procedūrų } \\
\text { teisingumas }\end{array}$} & \multirow{2}{*}{$\begin{array}{l}\text { Neatitinka PT } \\
\text { reikalavimų }\end{array}$} & $\begin{array}{l}\text { Iš dalies atitinka PT } \\
\text { reikalavimus }\end{array}$ & $-1,941$ & $\mathrm{p}<0,001$ \\
\hline & & $\begin{array}{l}\text { Visiškai atitinka PT } \\
\text { reikalavimus }\end{array}$ & $-2,362$ & $\mathrm{p}<0,001$ \\
\hline & $\begin{array}{l}\text { Iš dalies atitinka PT } \\
\text { reikalavimus }\end{array}$ & $\begin{array}{l}\text { Visiškai atitinka PT } \\
\text { reikalavimus }\end{array}$ & $-0,421$ & 0,002 \\
\hline \multirow{3}{*}{$\begin{array}{l}\text { Galimybė } \\
\text { išreikšti savo } \\
\text { nuomonę }\end{array}$} & \multirow{2}{*}{$\begin{array}{l}\text { Neatitinka PT } \\
\text { reikalavimų }\end{array}$} & $\begin{array}{l}\text { Iš dalies atitinka PT } \\
\text { reikalavimus }\end{array}$ & $-0,857$ & $\mathrm{p}<0,001$ \\
\hline & & $\begin{array}{l}\text { Visiškai atitinka PT } \\
\text { reikalavimus }\end{array}$ & $-1,307$ & $\mathrm{p}<0,001$ \\
\hline & $\begin{array}{l}\text { Iš dalies atitinka PT } \\
\text { reikalavimus }\end{array}$ & $\begin{array}{l}\text { Visiškai atitinka PT } \\
\text { reikalavimus }\end{array}$ & $-0,449$ & 0,003 \\
\hline \multirow[t]{3}{*}{ Etiškumas } & \multirow{2}{*}{$\begin{array}{l}\text { Neatitinka PT } \\
\text { reikalavimų }\end{array}$} & $\begin{array}{l}\text { Iš dalies atitinka PT } \\
\text { reikalavimus }\end{array}$ & $-2,764$ & $\mathrm{p}<0,001$ \\
\hline & & $\begin{array}{l}\text { Visiškai atitinka PT } \\
\text { reikalavimus }\end{array}$ & $-3,552$ & $\mathrm{p}<0,001$ \\
\hline & $\begin{array}{l}\text { Iš dalies atitinka PT } \\
\text { reikalavimus }\end{array}$ & $\begin{array}{l}\text { Visiškai atitinka PT } \\
\text { reikalavimus }\end{array}$ & $-0,788$ & $\mathrm{p}<0,001$ \\
\hline \multirow[t]{3}{*}{ Nešališkumas } & \multirow{2}{*}{$\begin{array}{l}\text { Neatitinka PT } \\
\text { reikalavimų }\end{array}$} & $\begin{array}{l}\text { Iš dalies atitinka PT } \\
\text { reikalavimus }\end{array}$ & $-1,345$ & $\mathrm{p}<0,001$ \\
\hline & & $\begin{array}{l}\text { Visiškai atitinka PT } \\
\text { reikalavimus }\end{array}$ & $-1,729$ & $\mathrm{p}<0,001$ \\
\hline & $\begin{array}{l}\text { Iš dalies atitinka PT } \\
\text { reikalavimus }\end{array}$ & $\begin{array}{l}\text { Visiškai atitinka PT } \\
\text { reikalavimus }\end{array}$ & $-0,384$ & 0,011 \\
\hline \multirow[t]{3}{*}{$\begin{array}{l}\text { Teisèjo } \\
\text { pastangos }\end{array}$} & \multirow{2}{*}{$\begin{array}{l}\text { Neatitinka PT } \\
\text { reikalavimų }\end{array}$} & $\begin{array}{l}\text { Iš dalies atitinka PT } \\
\text { reikalavimus }\end{array}$ & $-1,196$ & $\mathrm{p}<0,001$ \\
\hline & & $\begin{array}{l}\text { Visiškai atitinka } \mathrm{PT} \\
\text { reikalavimus }\end{array}$ & $-1,586$ & $\mathrm{p}<0,001$ \\
\hline & $\begin{array}{l}\text { Iš dalies atitinka PT } \\
\text { reikalavimus }\end{array}$ & $\begin{array}{l}\text { Visiškai atitinka PT } \\
\text { reikalavimus }\end{array}$ & $-0,389$ & 0,017 \\
\hline
\end{tabular}

* PT - procedūrinis teisingumas 
Statistinès analizès rezultatai atskleidžia, kad teisèjo elgesio atitikimas procedūrinio teisingumo reikalavimams daro statistiškai reikšmingą ( $\mathrm{p}<0,01)$ ịtaką jo elgesio ir sprendimo teisingumo vertinimams. Vis dèlto, analizuojant efekto dydi $\left(\eta^{2}\right)$, pastebima, kad teisèjo elgesio atitikimas procedūrinio teisingumo reikalavimams daro skirtingą ịtaką sprendimo, procedūrų teisingumo, suvoktos galimybès išreikšti savo nuomonę, etiškumo, nešališkumo ir suvoktų teisejjo pastangų vertinimams. Didžiausią poveikị teisèjo elgesio atitikimas procedūrinio teisingumo reikalavimams turèjo etiškumo $\left(\eta^{2}=0,607\right)$ ir suvokto procedūrinio teisingumo vertinimams $\left(\eta^{2}=0,38\right)$, o mažiausią - priimto sprendimo teisingumo vertinimams $\left(\eta^{2}=0,078\right)$.

Atlikta analizè atskleidè, kad teisėjo priimtą sprendimą kaip mažiausiai teisingą ivvertino tie tiriamieji, kurie stebejo neatitinkantị procedūrinio teisingumo reikalavimų teisèjo elgesị. Jų vertinimai statistiškai reikšmingai skyrèsi nuo sprendimo teisingumo vertinimų kitose (iš dalies ir visiškai procedūrinio teisingumo reikalavimus atitinkančio elgesio) tiriamųjų grupėse $(\mathrm{p}<0,01)$. Sprendimo teisingumo vertinimai dalinio ir visiško atitikimo procedūrinio teisingumo reikalavimams atvejais tarp tiriamųjų grupių statistiškai reikšmingai nesiskyrè $(\mathrm{p}=0,066)$. Be to, galima pastebèti tendenciją, kad kai teisèjo elgesys visiškai atitiko procedūrinio teisingumo reikalavimus, jo priimtas sprendimas buvo vertinamas kaip mažiau teisingas, palyginti su tais sprendimo teisingumo vertinimais, kai teisèjo elgesys iš dalies atitiko procedūrinio teisingumo reikalavimus.

Daugkartinio palyginimo rezultatai (žr. 3 lentelę) rodo, kad teisèjo elgesys buvo suprantamas kaip labiausiai teisingas tada, kai jis visiškai atitiko procedūrinio teisingumo reikalavimus, o kaip mažiausiai teisingas tada, kai jo elgesys visiškai neatitiko procedūrinio teisingumo reikalavimų $(\mathrm{p}<0,01)$. Atkreiptinas dèmesys, kad dalinio atitikimo procedūrinio teisingumo reikalavimams situacijoje pateikti tiriamųjų vertinimai statistiškai reikšmingai skyrèsi nuo kitų dviejų atvejų - tiek nuo teisèjo elgesio visiško atitikimo procedūrinio teisingumo reikalavimams, tiek ir nuo jų neatitikimo $(\mathrm{p}<0,01)$.

Siekdami ịvertinti asmenybės bruožų sąsajas su suvokto teisèjo elgesio ir priimto sprendimo teisingumo vertinimais, atlikome kovariacinę duomenų analizę. Nepriklausomu kintamuoju buvo pasirinktas teisejjo elgesio atitikimas procedūrinio teisingumo reikalavimams (visiškas atitikimas, dalinis atitikimas, neatitikimas), priklausomais - suvokto teisejjo elgesio ir priimto sprendimo teisingumo vertinimai. Tiriamųjų asmenybės bruožų skalių (neurotiškumo, ekstraversiškumo, atvirumo, sutarumo ir sąmoningumo) ịverčiai atliko kovariančių vaidmenį (žr. 4 lentelę). 
4 lentelè. Asmenybės bruožų ir suvokto teisèjo elgesio / priimto sprendimo teisingumo sąsajos skirtingomis teisèjo elgesio situacijomis

\begin{tabular}{|l|c|c|c|c|c|c|}
\hline \multicolumn{1}{|c|}{ Kovariantés } & \multicolumn{3}{c|}{$\begin{array}{c}\text { Priklausomas kintamasis: } \\
\text { Teisèjo sprendimo teisingumas }\end{array}$} & \multicolumn{3}{c|}{$\begin{array}{c}\text { Priklausomas kintamasis: } \\
\text { Teisèjo elgesio teisingumas }\end{array}$} \\
\hline & F reikšmè & p reikšmé & $\eta^{2}$ & F reikšmè & p reikšmé & $\eta^{2}$ \\
\hline Neurotiškumas & 3,176 & 0,076 & 0,009 & 0,033 & 0,857 & 0,001 \\
\hline Ekstraversija & 3,777 & 0,053 & 0,010 & 0,901 & 0,343 & 0,002 \\
\hline Atvirumas patyrimui & 1,307 & 0,254 & 0,004 & 0,304 & 0,582 & 0,001 \\
\hline Sutarumas & 1,076 & 0,300 & 0,003 & 0,079 & 0,779 & 0,001 \\
\hline Sąmoningumas & 0,321 & 0,571 & 0,001 & 5,627 & 0,018 & 0,015 \\
\hline
\end{tabular}

Kaip matyti iš 4 lentelèje pateiktų rezultatų, neurotiškumas, ekstraversija, atvirumas patyrimui, sutarumas ir sąmoningumas nesusiję su suvokto teisejjo sprendimo teisingumo vertinimais skirtingomis teisejo elgesio situacijomis ( $p>0,05)$. Kitaip tariant, teisèjo sprendimo teisingumo vertinimams penki baziniai asmenybės bruožai poveikio neturèjo.

5 lentele. Teisèjo elgesio teisingumo vertinimų palyginimas skirtingomis teisèjo elgesio situacijomis, atsižvelgiant ị sąmoningumo bruožą (daugkartinių lyginimų rezultatai)

\begin{tabular}{|c|c|c|c|c|}
\hline \multirow{4}{*}{$\begin{array}{l}\text { Priklausomas } \\
\text { kintamasis: } \\
\text { suvoktas teisejo } \\
\text { elgesio teisingu- } \\
\text { mas }\end{array}$} & $\begin{array}{l}\text { (I) Teisejo elgesio } \\
\text { atitikimas } P T^{*} \\
\text { reikalavimams }\end{array}$ & $\begin{array}{c}(J) \text { Teisèjo elgesio } \\
\text { atitikimas } P T \\
\text { reikalavimams }\end{array}$ & $\begin{array}{c}\text { Vidurkiu } \\
\text { skirtumas } \\
\quad(I-J)\end{array}$ & $\begin{array}{c}\text { Reikšmingumo } \\
\text { lygmuo }\end{array}$ \\
\hline & \multirow[t]{2}{*}{$\begin{array}{l}\text { Neatitinka PT } \\
\text { reikalavimų }\end{array}$} & $\begin{array}{l}\text { Iš dalies } \\
\text { atitinka PT } \\
\text { reikalavimus }\end{array}$ & $-1,540$ & 0,001 \\
\hline & & $\begin{array}{l}\text { Visiškai } \\
\text { atitinka PT } \\
\text { reikalavimus }\end{array}$ & $-1,734$ & 0,001 \\
\hline & $\begin{array}{l}\text { Iš dalies } \\
\text { atitinka PT } \\
\text { reikalavimus }\end{array}$ & $\begin{array}{l}\text { Visiškai } \\
\text { atitinka PT } \\
\text { reikalavimus }\end{array}$ & $-0,194$ & 0,199 \\
\hline
\end{tabular}

${ }^{*} P T$ - procedūrinis teisingumas

Ivertinus asmenybès bruožų ir suvokto teisèjo elgesio teisingumo sąsajas, nustatyta, kad vienintelis asmenybės bruožas, susijęs su suvokto teisèjo elgesio teisingumo vertinimais, - tai sąmoningumas ( $\mathrm{p}=0,018)$, o neurotiškumas, ekstraversija, atvirumas patyrimui ir sutarumas nèra susijęs su suvokto teisèjo elgesio teisingumo vertinimais $(\mathrm{p}>0,05)$ (žr. 4 lentelę). Vis dèlto, sąmoningumo poveikis suvokto teisèjo elgesio teisingumo vertinimams yra gana mažas $\left(\eta^{2}=0,015\right)$. Daugkartinių lyginimų 
rezultatai atskleidè (žr. 5 lentelę), kad skirtumai tarp teisėjo elgesio teisingumo vertinimų, atsižvelgiant ị sąmoningumą, pasireiškia tik tada, kai teisejjo elgesys neatitinka procedūrinio teisingumo reikalavimų $(\mathrm{p}<0,05)$, tačiau tada, kai teisejjo elgesys iš dalies arba visiškai atitinka procedūrinio teisingumo reikalavimus, statistiškai reikšmingų skirtumų tarp teisejjo elgesio teisingumo vertinimų nelieka ( $\mathrm{p}>0,05)$. Taigi galima teigti, kad suvokto teisèjo elgesio teisingumo vertinimai, atsižvelgiant i tiriamųjų sąmoningumą, statistiškai reikšmingai skyrèsi tada, kai teisèjo elgesys mažiausiai atitiko procedūrinio teisingumo reikalavimus.

\section{Rezultatų aptarimas}

Teisejjo elgesio pobūdžio ịtaka suvokto teisingumo vertinimams. Atlikdami tyrimą, siekème atskleisti teisejjo elgesio atitikimo procedūrinio teisingumo reikalavimams itaką suvokto teisejjo elgesio ir priimto sprendimo teisingumo vertinimams (kai tiriamieji, susitapatinę su nukentejjusiuoju, sulaukia nepalankaus teismo sprendimo). Nustatyta, kad teisejo elgesio atitikimas procedūrinio teisingumo reikalavimams daro reikšmingą ịtaką tiek teisėjo elgesio, tiek priimto sprendimo teisingumo vertinimams. Tačiau ši įtaka yra nevienoda. Pavyzdžiui, teisėjo elgesio atitikimas procedūrinio teisingumo reikalavimams turi didelị poveikị jo elgesio teisingumo vertinimams, tačiau teisejjo elgesio pobūdžio ịtaka jo priimto sprendimo teisingumo vertinimams yra labai silpna (nors ir statistiškai reikšminga). Taigi gauti duomenys leidžia teigti, kad, esant nepalankiam sprendimui, teisèjo elgesio atitikimas procedūrinio teisingumo reikalavimams daro didelę ittaką suvokto teisejjo elgesio teisingumo vertinimams. Kuo teisejjo elgesys labiau atitinka procedūrinio teisingumo reikalavimus, tuo labiau jis suvokiamas kaip teisingas.

Teisejjo elgesio atitikimo procedūrinio teisingumo reikalavimams ịtaka buvo nevienoda skirtingiems suvokto teisèjo elgesio vertinimų aspektams. Didžiausia ji buvo teisėjo elgesio etiškumo vertinimams, šiek tiek mažesnè - nešališkumo ir procedūrinio teisingumo vertinimams ir mažiausia - suvoktai galimybei išreikšti savo nuomonę teismo proceso metu bei teisèjo pastangų vertinimui. Taigi gauti duomenys rodo, kad tiriamieji, vertindami teisejjo elgesį, nemažai dèmesio skyrè nukentejjusiojo ir teisèjo tarpasmeninès sąveikos aspektams. Teisèjo ir piliečio tarpasmeninès sąveikos reikšmę bylinėjimosi proceso metu galima paaiškinti remiantis skirtingais procedūrinio teisingumo modeliais. Mūsų manymu, gautus rezultatus geriausiai paaiškina dviejų komponentų procedūrinio teisingumo modelis ${ }^{30}$. T. R. Tyler ir S. L. Blader teigimu, atlikdami teisingumo vertinimus, žmonès visų pirma atkreipia dèmesị $\mathfrak{i}$ tas procedūrų charakteristikas, kurios leidžia ịvertinti, kaip yra priimamas sprendimas (pvz., ar teisèjas suteikia ginčo dalyviams galimybę išreikšti savo nuomonę). Šie procedūrų aspektai leidžia numatyti galimus ginčo sprendimo padarinius. Vis dèlto šių 
charakteristikų teisingumo vertinimams atlikti nepakanka, kadangi didelè reikšmė atitenka ginčo sprendimo situacijos socialinès-psichologinès atmosferos ịvertinimui, t. y. žmonių dèmesio centre atsiduria teisejo elgesio su ginčo šalimi ypatumai. Tarpasmeninès sąveikos ypatumai gali būti visiškai nesusiję su objektyviu priimto sprendimo teisingumu, bet jie yra ne mažiau reikšmingi, atliekant teisingumo vertinimus. Tyrimai patvirtina, kad tarpasmeninès sąveikos ypatumai suteikia žmonèms informacijos apie jų užimamą statusą ${ }^{31}$. Kitaip tariant, kai su žmonèmis elgiamasi mandagiai, pagarbiai ir nešališkai, jie vertina save kaip vertingus socialinès grupès narius. Taigi formuojantis subjektyviems teisingumo arba neteisingumo vertinimams yra svarbūs tiek sprendimo prièmimo, tiek tarpasmeninès sąveikos ypatumai. Tačiau reikia paminèti, kad priklausomai nuo situacijos konteksto vienas arba kitas komponentas gali turèti didesnę ịtaką ${ }^{32}$.

Nustatyta statistiškai reikšminga silpna teisèjo elgesio pobūdžio įtaka suvokto sprendimo teisingumo vertinimams. Gauti duomenys leidžia teigti, kad, esant nepalankiam sprendimui, teisejjo elgesio atitikimas procedūrinio teisingumo reikalavimams daro ịtaką suvokto sprendimo teisingumo vertinimams. Kitaip tariant, netgi nepalankaus teisejo sprendimo atveju teisejo elgesys lemia sprendimo teisingumo vertinimo ypatumus. İdomu, kad teisejjo priimtas sprendimas buvo vertinamas kaip labiausiai neteisingas tada, kai jo elgesys mažiausiai atitiko procedūrinio teisingumo reikalavimus, tačiau kai jo elgesys iš dalies arba visiškai atitiko procedūrinio teisingumo reikalavimus, jo suvokto sprendimo teisingumo vertinimai nesiskyrè. Šie rezultatai gali reikšti tai, kad sprendimo teisingumo vertinimams didelę reikšmę turi tai, ar apskritai teisèjo elgesys atitinka procedūrinio teisingumo reikalavimus (iš dalies arba visiškai). Nustatyti dèsningumai patvirtina ankstesnius suvokto teisingumo tyrimus, atskleidžiančius, kad nepalankus rezultatas, pasiektas teisingomis procedūromis, yra suprantamas kaip mažiau neteisingas ${ }^{33}$.

Nustatyta teisèjo elgesio pobūdžio ịtaka suvoktam jo elgesio ir priimto sprendimo teisingumui (nepalankaus sprendimo atveju) taip pat gali būti paaiškinta remiantis referentinių kognicijų teorija (RKT). RKT kelia prielaidą, kad žmonés vertina priimamus sprendimus, lygindami juos su tam tikrais įsivaizduojamais sprendimais ${ }^{34}$.

31 Tepper, B. J.; Eisenbach, R. J.; Kirby, S. L.; Potter, P. W. Test of a Justice-Based Model of Subordinates' Resistance to Downward Influence Attempts. Group and Organization Management. 1998, 23(2):144-160;Tyler, T. R.; Lind, E. A. A relational model of authority in groups. Advances in experimental social psychology. 1992, 25: 115-191; Folger, R.; Skarlicki, D. P. A popcorn metaphor for workplace violence. Dysfunctional behavior in organizations, Violent behaviors in organizations. Greenwich: JAI Press, 1998. p. 43-81; Lind, E. A.; Tyler, T. R.. supra note 1.

32 Tyler, T. R.; Blader, S., supra note 30.

33 Törnblom, K. Y.; Vermunt, R. An integrative perspective on social justice: Distributive vs. procedural fairness evaluations of positive and negative outcome allocations.Social Justice Research. 1999, 12(1): 37-61.

34 Cropanzano, R.; Folger, R. Referent cognitions and task decision authonomy: Beyond equity theory. Journal of Applied Psychology. 1989, 4(2): 293-299; Van den Bos, K.; Van Prooijen, 
Jeigu sprendimas neatitinka turètų lūkesčiu, tada ieškoma to neatitikimo priežasčių, todèl didesnis dèmesys skiriamas taikytos procedūros analizei. Taigi, esant nepalankiam sprendimui (neatitikimas turètų lūkesčių), teisejjo elgesio atitiktis procedūrinio teisingumo reikalavimams yra svarbi tiek sprendimo, tiek ir teisèjo elgesio teisingumo vertinimams.

Asmenybės bruožų ir suvokto teisingumo vertinimu sąajos. Atliktas tyrimas neatskleidè priimto sprendimo teisingumo vertinimų ir penkių bazinių (neurotiškumo, ekstraversiškumo, atvirumo patyrimui, sąmoningumo ir sutarumo) asmenybės bruožų sąsajų skirtingomis teisejo elgesio situacijomis. Naujausi užsienio autorių tyrimai patvirtina asmenybės bruožų ir skirstymo teisingumo sąsajas ${ }^{35}$, tačiau juose buvo tiriamos emocinès tiriamųjų reakcijos ị suvoktą neteisingumą, todèl šių rezultatų negalima lyginti su mūsų gautais duomenimis.

Tiriamųjų suvokto teisèjo elgesio teisingumo vertinimai, skirtingomis teisèjo elgesio situacijomis nesiskyré, kai buvo atsižvelgiama į keturis bazinius asmenybès bruožus (neurotiškumą, ekstraversiją, atvirumą patirčiai ir sutarumą). Šie duomenys rodo, kad teiséjo elgesio atitikimas procedūrinio teisingumo reikalavimams, palyginti su anksčiau išvardintais asmenybès bruožais, turi didesnę įtaką teisingumo vertinimams. Taigi, galima teigti, kad teisèjo elgesio atitikimas procedūrinio teisingumo reikalavimams yra reikšmingesnis kintamasis negu individualios asmenybès charakteristikos (pvz., tokie bruožai kaip neurotiškumas, ekstraversiškumas, atvirumas patirčiai ir sutarumas). Gauti duomenys nepatvirtina organizacinio teisingumo tyrimų rezultatų, atskleidžiančių neurotiškumo ir sutarumo sąsajas su suvoktu teisingumu ${ }^{36}$. Kartu reikia pažymèti, kad mes tyrėme pakankamai neiprastą situaciją - bylinėjimosi procesą, kurị sunku tiesiogiai palyginti su kasdienemis situacijomis organizacijose. Todèl, norint atskleisti asmenybès bruožų ir suvokto teisingumo (teismo proceso metu) ryšius, reikia atlikti tolesnius tyrimus.

Nustatyta, kad sąmoningumas - tai vienintelis Didžiojo penketo asmenybès bruožas, kuris turẻjo ịtakos teisingumo vertinimams, kai teisèjo elgesys neatitiko procedūrinio teisingumo reikalavimų (t. y. buvo taikomos neteisingos procedūros). Aukšti sąmoningumo bruožo ịverčiai siejami su taisyklių laikymusi ir polinkiu priimti valdžios atstovų sprendimus ${ }^{37}$. Todèl galima manyti, kad asmenys, kuriems būdingas stipriai išreikštas sąmoningumas, linkę suprasti teisèjo elgesį kaip neginčytiną, taip pat yra mažiau jautrūs teisingumo principų pažeidimams. Kita vertus, asmenys,

J.-W. Referent cognitions theory: The role of closeness of reference points in the psychology of voice. Journal of Personality and Social Psychology. 2001, 81(4): 616-626.

35 Stouten, J.; Kuppens, P.; Decoster, S. Being angry for different reasons: the role of personality in distributive justice. Journal of Applied Psychology. 2013, 43(4): 795-805.

36 Skarlicki, D. P.; Folger, R.; Tesluk, P. Personality as a moderator in the relationshipbetween fairness and retaliation. Academy of Management Journal. 1999, 42(1): 100-108; Shi, J.; Lin, H.; Wang, L., supra note 16; Judge, T. A.; Locke, E. A.; Durham, C. C.; Kluger, A. N. Dispositional effects on job and life satisfaction: The role of core evaluations. Journal of Applied Psychology. 1998, 83(1): 17-34. Stouten, J.; Ceulemans, E.; Timmerman, M. E.; Van Hiel, A., supra note 7. 
pasižymintys žemu sąmoningumu, gali būti linkę mažiau vadovautis teisingumo ir moralès principais, be to, atlikdami veiklą, jie gali ieškoti naudos tik sau. Todèl galima manyti, kad dèl šių priežasčių, asmenys, pasižymintys žemu sąmoningumu, buvo labiau linkę vertinti situaciją, kurioje buvo priimtas jiems nepalankus sprendimas, kaip neteisingą (palyginti su tais, kuriems būdingas aukštas sąmoningumas). Vis dèlto, reikia pažymėti, kad nustatytas sąmoningumo poveikis suvokto teisingumo vertinimams yra labai nedidelis ir paaiškina tik vieną procentą vertinimų dispersijos. Be to, atliktame tyrime buvo analizuojami tik Didžiojo penketo teorijos išskirti asmenybės bruožai. Atliekant tolesnius tyrimus reikètų atsižvelgti ir ị kitas individualias charakteristikas, galinčias turèti ịtakos bylinejjimosi proceso teisingumo suvokimui (pvz., jautrumą teisingumui ${ }^{38}$, tikejjimą pasaulio teisingumu ${ }^{39}$ ir pan.).

Taigi mūsų gauti duomenys dar kartą patvirtina, kad, siekiant užtikrinti bylinèjimosi proceso dalyvių suvoktą teisingumą, visų pirma reikia, jog teisejjas laikytųsi procedūrinio teisingumo reikalavimų. Galimybẻ ginčo dalyviams išreikšti savo nuomonę, išsamus informavimas apie taikomas procedūras, nešališkas, etiškas ir pagarbus teisèjo elgesys bylinėjimosi proceso metu yra gyvybiškai svarbūs tam, kad ginčo dalyviai vertintų teismo priimtą sprendimą ir taikytas procedūras kaip teisingas.

\section{Išvados}

1. Kai priimtas sprendimas asmeniui yra nepalankus, teisejo elgesio atitikimas procedūrinio teisingumo reikalavimams daro stiprią ịtaką jo elgesio teisingumo vertinimams (kuo labiau teisèjo elgesys atitiko procedūrinio teisingumo reikalavimus, tuo labiau jis buvo suprantamas kaip teisingas), taip pat silpną, nors vis dar statistiškai reikšmingą $(\mathrm{p}<0,01)$ įtaką jo priimto sprendimo vertinimams (kai teisèjo elgesys neatitiko procedūrinio teisingumo reikalavimų, jo priimtas sprendimas buvo vertinamas kaip daug mažiau teisingas).

2. Nustatytos šios teisèjo suvokto elgesio teisingumo, jo priimto sprendimo teisingumo ir asmenybės bruožų sąsajos:

2.1. suvokto teisèjo elgesio teisingumo vertinimams didžiausią j̣taką turi jo elgesio pobūdis, o asmenybès bruožų ir teisėjo suvokto elgesio teisingumo ryšiai pasireiškia tik atskirais atvejais;

2.2. sąmoningumas yra vienintelis penkių faktorių asmenybės bruožas, susijęs su suvokto teisejjo elgesio teisingumo vertinimais (kai taikomos procedūros neatitinka, iš dalies atitinka arba visiškai atitinka procedūrinio teisingumo reikalavimus), tačiau šio bruožo poveikis suvokto teisingumo vertinimams yra nedidelis;

38 Schmitt, M.; Dörfel, M., supra note 4.

39 Hagedoorn, M.; Buunk, B. P.; van de Vliert, E. Do Just World Believers Process Unfair Authoritative Decisions Differently? Applied Psychology: An International Review. 2002, 51(1): 126-145. 
2.3. visi penkių faktorių asmenybės bruožai (neurotiškumas, ekstraversiškumas, sutarumas, atvirumas patirčiai ir sąmoningumas) yra nesusiję su teisejo priimto sprendimo teisingumo vertinimais (kai taikomos procedūros neatitinka, iš dalies atitinka arba visiškai atitinka procedūrinio teisingumo reikalavimus).

\section{Literatūra}

Baumert, A.; Schmitt, M. Justice sensitive interpretations of ambiguous situations. Australian Journal of Psychology. 2009, 61(1).

Colquitt, J. A.; Scott B. A.; Judge T. A.; Shaw J. C. Justice and personality: Using integrative theories to derive moderators of justice effects. Organizational Behavior and Human Decision Processes. 2006, 100(1).

Costa, P. T.; McCrae, R. R. Revised NEO Personality Inventory (NEO-PI-R) and NEO Five-Factor Inventory (NEO-FFI) professionalmanual. Odessa: Psychological Assessment Resources, 1992.

Cropanzano, R.; Folger, R. Referent cognitions and task decision autonomy: Beyond equity theory. Journal of Applied Psychology. 1989, 4(2).

De Kwaadsteniet, E. W.; Van Dijk, E.; Wit, A.; De Cremer, D. Social dilemmas as strong versus weak situations: Social value orientations and tacit coordination under resource uncertainty. Journal of Experimental Social Psychology. 2006, 42(4).

Elliott, I.; Thomas, S. D. M.; Ogloff, J. R. P. Procedural justice in contacts with the police: Testing a relational model of authority in a mixed methods study. Psychology, Public Policy, and Law. 2011, 17(4).

Folger, R.; Skarlicki, D. P. A popcorn metaphor for workplace violence. Dys- functional behavior in organizations. Violent behaviors in organizations. Greenwich: JAI Press, 1998.

Hagedoorn, M.; Buunk, B. P.; van de Vliert, E. Do Just World Believers Process Unfair Authoritative Decisions Differently? Applied Psychology: An International Review. 2002, 51(1).

Huseman, R. C.; Hatfield, J. D.; Miles, E. W. A new perspective on Equity Theory: The Equity Sensitive Construct. Academy Management Review. 1987, 12(2).

Judge, T. A.; Locke, E. A.; Durham, C. C.; Kluger, A. N. Dispositional effects on job and life satisfaction: The role of core evaluations. Journal of Applied Psychology. 1998, 83(1).

Justickis, V.; Valickas, G. Procedūrinis teisingumas Lietuvos kriminalineje justicijoje. Vilnius: Mykolo Romerio universitetas, 2006.

Laurinavičius, A. Procedūrinio teisingumo psichologiniai veiksniai: Teisejo sprendimo prognozés itaka teisingumo vertinimams. Daktaro disertacija. Socialiniai mokslai, psichologija. Vilnius: Vilniaus universitetas, 2006.

Lilly, J. D.; Virick, M. The effect of personality on perceptions of justice. Journal of Managerial Psychology. 2006, 21 (5).

Lind, E. A.; Tyler, T. R. The social psychology of procedural justice. New York: Plenum Press, 1988. 
Magnus, K.; Diener, E.; Fujita, F.; Pavot, W. Extraversion and neuroticism as predictors of objective life events; a longitudinal study. Journal of Personality and Social Psychology. 1993, 65(5).

Orth, U. Secondary victimization of crime victims by criminal proceedings. Social Justice Research. 2002, 15(4).

Pakalniškienè, V. Tyrimo ir ịvertinimo priemoniu patikimumo ir validumo nustatymas. Metodinè priemonè. Vilnius: VU leidykla, 2012.

Schmitt, M.; Dörfel, M. Procedural injustice at work, justice sensitivity, job satisfaction and psychosomatic well-being. European Journal of Social Psychology. 1999, 29(4).

Schmitt, M. Individual differences in sensitivity to befallen injustice (SBI). Personality and individual differences. 1996, 21(1).

Schmitt, M. Individual differences in sensitivity to befallen injustice (SBI). Personality and Individual Differences. 1996, 21(1).

Shi, J.; Lin, H.; Wang, L.; Wang, M. Linking the Big Five Personality Constructs to Organizational Justice. Social Behavior and Personality. 2009, 37(2).

Skarlicki, D. P.; Folger, R.; Tesluk, P. Personality as a moderator in the relationship between fairness and retaliation. Academy of Management Journal. 1999, 42(1).

Snyder, M.; Ickes, W. Personality and social behavior. Handbook of social psychology. 3rd edition. New York: Random House, 1985.

Stouten, J.; Ceulemans, E.; Timmerman, M. E.; Van Hiel, A. Tolerance of Justice Violations: The Effects of Need on Emotional Reactions After Violating Equality in Social Dilemmas. Journal of Applied Social Psychology. 2011, 41(2).
Stouten, J.; Kuppens, P.; Decoster, S. Being angry for different reasons: the role of personality in distributive justice. Journal of Applied Psychology. 2013, 43(4).

Thibaut J.; Walker, L. Procedural justice. Hillsdale, New Jersey: Lawrence Erlbaum, 1975.

Törnblom, K.Y.; Vermunt, R. An integrative perspective on social justice: Distributive vs. procedural fairness evaluations of positive and negative outcome allocations. Social Justice Research. 1999, 12(1).

Tyler, T. R.; Lind, E. A. A relational model of authority in groups. Advances in experimental social psychology. 1992, 25.

Tyler, T. R. Social justice: Outcome and procedure. International Journal of Psychology. 2000, 35(2).

Tyler, T. R.; Blader, S. Cooperation in groups: Procedural justice, social identity, and behavioral engagement. Philadelphia: Psychology Press, 2000.

Van den Bos, K.; Van Prooijen, J.-W. Referent cognitions theory: The role of closeness of reference points in the psychology of voice. Journal of Personality and Social Psychology. 2001, 81(4).

Wiggins, J. S.; Trapnell, P. D. Personality structure: The return of the Big Five. Handbook of personality psychology. San Diego: Academic Press, 1997.

Wolfradt, U.; Dalbert, C. Personality, Values and Belief in a Just World. Personality and Individual Differences. 2002, 35(8).

Wrenn, K. A. The Big Five as Predictors of Procedural Justice Perceptions. Georgia: Georgia Institute of Technology, 2005. 
Ksenija Čunichina, Vilniaus universiteto Filosofijos fakulteto Bendrosios psichologijos katedros lektorè. Mokslinių tyrimų kryptis: teisès psichologija.

Ksenija Čunichina, Vilnius University, Faculty of Philosophy, Department of General Psychology, Lecturer. Research interest: forensic psychology.

Gintautas Valickas, Vilniaus universiteto Filosofijos fakulteto Bendrosios psichologijos katedros profesorius. Mokslinių tyrimų kryptys: teisès psichologija, procedūrinis teisingumas, streso įveika, pareigūnų atranka ir konsultavimas.

Gintautas Valickas, Vilnius University, Faculty of Philosophy, Department of General Psychology, Professor. Research interests: forensic psychology, procedural justice, coping with stress, officers selection and consultation.

Viktoras Justickis, Mykolo Romerio universiteto Socialinės politikos fakulteto Psichologijos katedros profesorius. Mokslinių tyrimų kryptys: teisè, kriminologija, psichologija.

Viktoras Justickis, Mykolas Romeris University, Faculty of Social Policy, Department of Psychology, Professor. Research interests: law, criminology, psychology. 